In Nottingham the course organiser chooses the first attachment (as this is the only organisational model possible) and the trainee the second. In making this second choice the following factors are considered: the personality of the trainee and the trainer, the interests of both trainee and trainer, and the trainee's future career hopes. We attempt to provide two teaching practices that provide as different an experience as possible in terms of the trainer's personality, teaching style, partnership premises, and practice management.

If two practices are used it is even more important that trainees and trainers are prepared for each other. The trainee will have to both participate and observe and the trainer has to assess more perceptively and then meet the individual needs of the trainee.

MichaEL VARNAM Course organiser, Nottingham Vocational Training Scheme, and Assistant Adviser in General Practice to
Nottingham University

Ilkeston, Derbyshire DE7 5PR

\section{Manpower and training}

SIR,-I have read with interest the letters of Sir Henry Yellowlees and Dr S L O Jackson (24 January, pp 319 and 320) concerning the dismal promotion prospects for many trainees in the hospital service.

My experience is somewhat similar to that of Dr Jackson, in that recently 37 applicants applied for a post as senior registrar in general surgery at this hospital. Twenty-two of the applicants were graduates of British universities, and the remainder were from overseas. The average age of the whole group was 33.2 years and the UK graduates 31.7 years. The average number of years since qualification of the whole group was $9 \cdot 4$ and of the UK graduates 8.0 years. A large number of the applicants were eminently suitable for promotion to senior registrar, having considerable practical experience, multiple higher qualifications, and first-class references. Many had spent time in centres of excellence in the UK or the United States, and had contributed time and energy to research and publication of medical papers I am aware that promotion in general surgery has never been easy, but cannot help wondering if my experience is reflected throughout the United Kingdom-whether the competition at present is so severe that there is very little prospect of the vast majority of surgical registrars ever reaching senior registrar status.

I was heartened to read that staff from the DHSS will shortly be approaching regional health authorities and royal colleges with a view to setting up discussions on this subject. I hope that these meetings will include representatives of the junior staff (from the $\mathrm{UK}$ and overseas) as it is their future which is at stake and not that of the present generation of consultants.

IAN F KERR

\section{Surgical Division, \\ Stobhill General Hospital,}

\section{Manpower planning and accurate information}

SIR,-Professor M D Vickers (10 January, p 151) takes us to task in his interpretation of the letter by one of us (RSV) (15 March $1980, \mathrm{p}$ 796). He is quite wrong when he implies a widespread and continuing creation of illicit registrar posts in the South-west Thames Region. Instances we have come across happened some years ago and there is certainly no policy of this nature in the SW Thames Region, as is alleged to occur in other regions (2 February 1980, p 344).

Our information system is primarily concerned with postgraduate medical education and the manpower data is a spin-off. We rely on the friendly co-operation we enjoy with NHS medical staffing personnel; acting as "big brother" would destroy this spirit and the system. The instances relating to the registrar posts quoted in the March letter indicated a disparity about posts recognised at district level for which manpower approval had not been sought. The evidence requested by Professor Vickers lies somewhere between district, area, and regional administration and is outside our jurisdiction. Professor Vickers's public confidence in DHSS retribution is not reflected in our private correspondence with him, which we, unlike him, consider personal and privileged. The DHSS if it wished could obtain the data to confirm what has taken place in the past in the SW Thames Region in relation to registrar posts, which Professor Vickers says has gone on widely in anaesthesia.

The need for accurate data is not in question, as discussed in your leading article (3 March 1979, p 573) and numerous other places. We have demonstrated that it can be obtained in SW Thames Region and could also be obtained for other regions and supplied to the DHSS. If the DHSS does not have the data to monitor the situation it is difficult to see how any region prepared to ignore the rules concerning the creation of posts can be effectively exposed, let alone punished as Professor Vickers suggests.

George Dick R S VINER

Regional Office,

ritish Postgraduate Medical

Federation,

Mortality, morbidity, and resource allocation

SIR,-We too would like to support the views of $\mathrm{Dr} M \mathrm{~J}$ Goldacre and Mr R I Harris (6 December, p 1515) and those expressed in subsequent correspondence by $\mathrm{Dr} R$ J West, Dr William M Patterson, and Mr P A West (10 January, p 151). These authors attest that in hospitals mortality, bed usage, and International Classification of Diseases chapter diagnoses do not correlate in a manner appropriate for the allocation of funds at district and regional levels. Much health care takes place in the community and admissions often depend on social factors. Dr Goldacre and $\mathrm{Mr}$ Harris draw attention to the assumption that mortality rates are a suitable proxy for morbidity.

We believe that the "attractive simplicity" of mortality statistics as a measure of a population's health status could be replaced by a more relevant parameter-for example, the prevalence of pressure sores in the whole population (that is, community and hospital). This parameter is relevant to the living and the dying, and reflects preventable morbidity caused by deficits in social, remedial, "hotel," nursing, and medical care, whether acute or chronic. Furthermore, its determination by outsiders would provide a true audit of care for a district and evidence of waste of resources occasioned by failure of prevention.

\section{A A BARTON \\ MARY BARTON \\ ROSEMARY CROW \\ R DYSON}

M R P HALL

H J Glanville

D C MCNEILL

J C ROBERTSON

Tissue Viability Group

c/o Wessex Rehabilitation Association,

Odstock Hospital,

Salisbury, Wilts

\section{More about ancient Egyptian}

SIR,-It was interesting to read Dr John Nunn's letter (22 November, p 1430), which shows that the word cat in the ancient Egyptian language was similar phonetically to the same word in other languages. I would like to point out that the word medicine is derived from the ancient Egyptian word sinw, which means doctor; this was carried on into Coptic, which is the continuation of the ancient Egyptian language using Greek letters with the addition of seven more. It is worth noting that the symbols for sinw refer to medicine and surgery: thus medicine does not apply exclusively to physicians. Also the word chemistry comes from Kimi, which is said to mean Egypt in the ancient Egyptian language, as the Egyptians were renowned for their ingenuity in chemistry. The Arabic expression is also formed from the same word.

It is of interest that the Western alphabet is derived from the hieroglyphs. ${ }^{1}$ Thus the letter A originates from the sign of an eagle. The Phoenicians, being men of trade, had no time to write the complicated hieroglyphs and were content with the head of the eagle to denote the first letter of the alphabet. This was transferred to Greece and became the Western A.

With reference to Dr B J Freedman's note (18 October, p 1060), one recalls Shakespeare: "I had rather be a kitten and cry mew" (Henry IV Part I (Act III, Scene 1, 129). I confirm that Egyptian cats nowadays say "miow-miow" and dogs bark "haow-haow." It is worth recalling that the Pharaoh hounds are similar in appearance to some dogs depicted in some tomb drawings from Ancient Egypt: hence the name. It is believed that they originated from Malta and we do see them occasionally in England. It will be interesting to study their bark to see whether it is Egyptian, Maltese, or English.

Among the human race, it is only the very deaf who have a common sign language, which enables them to communicate wherever they are and whatever their native language is.

Ahmes L Pahor

ENT Departments

Road and Sandwell

District General Hospitals,

OR N

1 Breasted JH. A history of Egypt. 2nd ed. New York:

Charles Scribner's Sons, $1909: 484$.

\section{Correction}

Out of step

In the letter by Mr E Grattan (24 January, p 316) we regret that an error occurred in the last paragraph, lines 6 and 7: "population explosions of $\vec{c}$ this country" should read ". . of this century."

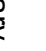

